Our Nature (2005)3:42-49

\title{
Nomads and Pastoralism: Linkage with Biodiversity Conservation in Upper Mustang, Nepal
}

\author{
M.R. Pandey and M. Chetri \\ King Mahendra Trust for Nature Consercation-ACAP/UMBCP
}

\begin{abstract}
In this paper we attempted to present a glimpse of linkage between the nomads living in the pasture of Upper Mustang and their role in biodiversity conservation. The nomadic rangeland in Upper Mustang region harbors endangered Trans-Himalayan species like snow leopard, lynx, brown bear, Tibetan wild ass, Tibetan argali etc. with a variety of birds. It also harbors various medicinal species endemic to the region. Nomads are completely dependent on the livestock for the sustenance of their livelihood. There are only nine nomads families residing in rangelands of Upper Mustang, among them three families are resided in LoManthang Panga area whereas four families in Dhalung/Chhujung area and one each in Lauchhe/Dhaknak area and Ghami Lekh area. Seasonal grazing is a customary practice for all nomadic families. Interview with the nomads $(\mathrm{N}=9)$ reveals that the grass availability in the pastures is in decreasing trend. They reveal increase in the number of snow leopard and blue sheep whereas the population of Tibetan Gazelle is in decreasing trend. Rijiphuwa and Pika are the two sites in Dhalung/Chhujung area where snow leopard and grey wolf are the main problem creators. In Lauchhe area (summer pasture) and Dhaknak area (summer pasture), grey wolf and snow leopard are the main problem animals. In comparison to other pasture, the families of Dhalung/Chhujung area faces higher number of livestock losses. Nomads use their own traditional measures to protect their livestock against predators. Large flocks of goats/sheep often come from Tibet to Dhalung/Chhujung area which increases the pressure during the summer and is also the root cause for the deterioration of the pasture. The daily activities of Tibetan nomads have created disturbances resulting adverse impacts on the biodiversity. During summer, the habitat of Tibetan gazelle and Tibetan wild ass is badly affected.
\end{abstract}

Key words: Biodiversity, conservation, nomad, pastoralism, Upper Mustang

\section{Introduction}

The rapidly changing lifestyle with the new Mustang, among them 3 families ${ }^{1}$ are discovery of the luxury items from the residing in Lo-Manthang Panga area whereas developed world affects the lifestyle of the 4 families in Dhalung/Chhujung area. Other 2 people throughout the universe. Nomads are families are found one each in Chhonup and also not the exception. The number of Ghami Village Development Committees families is decreasing day by day and they (VDC) as well. They are locally known as started settling in certain villages. In Upper 'Dhokpa'. Nomads are completely dependent Mustang no data is available but interview on the livestock for the sustenance of their with the nomads reveal that there were more livelihood. They normally lead a migratory than 30 families only in the life, moving to somewhat warmer regions Dhalung/Chhujung area before 25-30 years. within a short territory during the winter At present there are only nine nomads months. Their existing traditional herding families residing in rangelands in Upper

\footnotetext{
${ }^{1}$ One family is recently splitted into two.
} 
M. R. Pandey and M. Chetri / Our Nature (2005)3:42-49

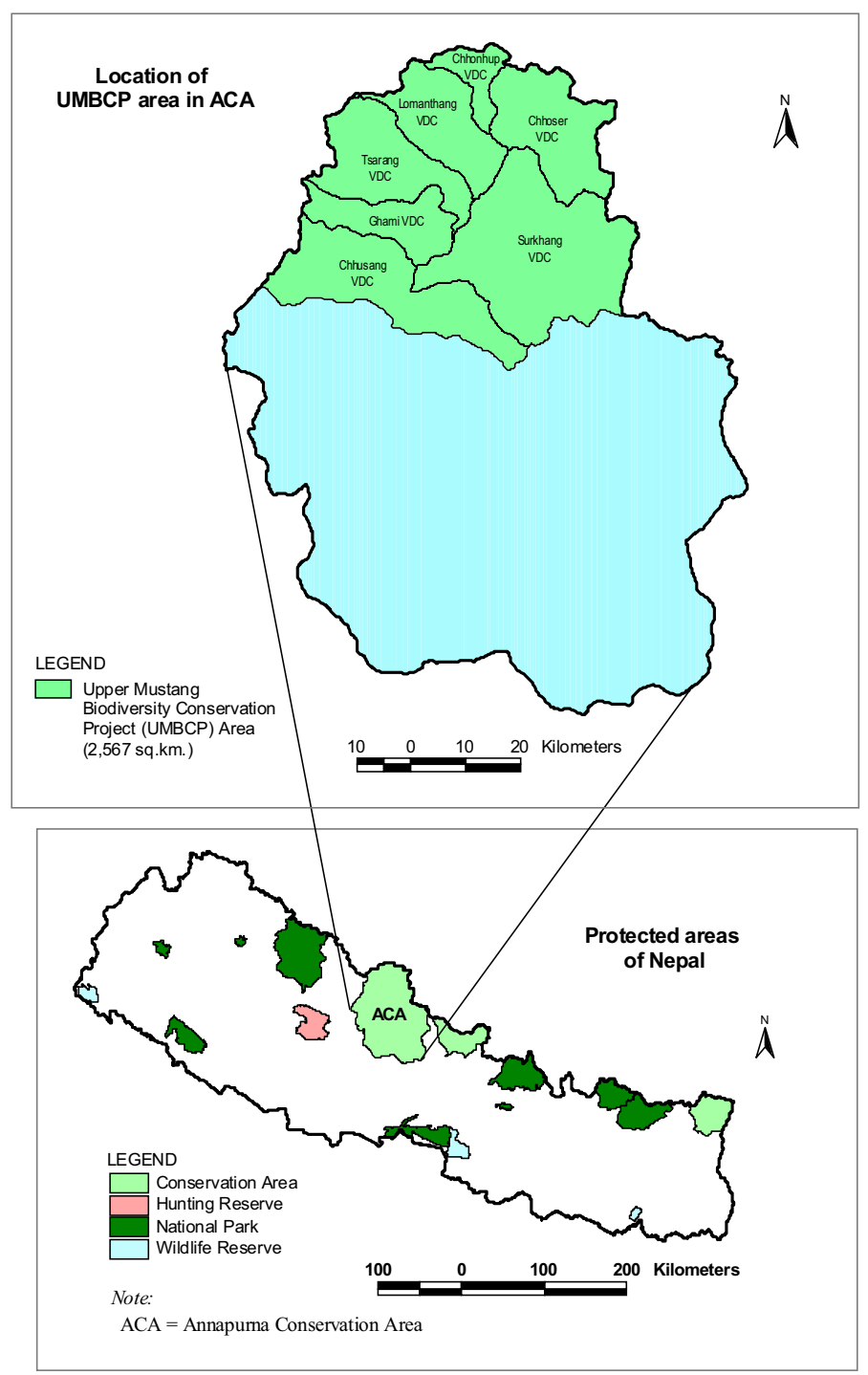

Map 1. Map of study area 
system and livestock keeping have both red fox, gray wolf, blue sheep, Tibetan wild positive and negative aspect in overall ass, Tibetan argali, Himalayan marmot with a biodiversity conservation in this ecologically variety of birds like snow partridge, Tibetan fragile ecosystem.

These high and very dry mountainous areas are extremely fragile and contain some very important high altitude biodiversity characteristics of the Trans-Himalayan Plateau. The area has very dry and limited quality pasture exists in isolated pockets which are the important habitat of rare and endangered mammals. These pastures are also important source for the livelihood of the local people and particularly the nomadic families. The endangered animal species like snow leopard, lynx, brown bear, and variety of birds' species with unique floral species of this region have added more splendors to this region.

King Mahendra Trust for Nature Conservation (KMTNC)-Annapurna Conser- vation Area Project (ACAP)/Upper Mustang Biodiversity Conservation Project (UMBCP) has been working in this area with aims to link biodiversity and cultural heritage conservation with tourism management. Therefore this paper is based on the study carried out for the biodiversity conservation plan and as a part of conservation area management plan preparation of this area.

This paper presents a glimpse of the linkage between the nomads living in the north-eastern, western, north-western and south-western area of Upper Mustang and livestock and their role in biodiversity conservation.

\section{Biodiversity of Upper Mustang} snow cock, Tibetan sandgrouse, chukor partridge, Himalayan griffon, choughs etc. glorify the high altitude faunal diversity. Moreover, Poa mustangensis, Clematis bractolata, Thymus linearis, Corydalis, Delphinium, Meconopsis etc. are some of the plant species unique for the region. All the dhokpa residing areas are the important areas in terms of biodiversity, especially rangeland biodiversity. In all the four dhokpa areas, the carnivores like snow leopard, lynx, red fox, gray wolf, and Himalayan brown bear, and their prey species such as blue sheep, marmots, wooly hare and pika harbor. Additionally in Dhalung/Chhujung area Tibetan wild ass, Tibetan Gazelle and Tibetan argali can also be seen. The highly endangered and commercially valuable Tibetan antelope or chiru is also suspected to occur within this area (Shah, 2001). The land also harbors rare birds such as Tibetan sandgrouse and is important migratory corridor for majority of the migratory birds visiting Nepal. Considering flora, the most dominant significant plant species in the areas are Kobressia sp., Carex sp., Lonicera obovata, Ephedra gerardiana, Spiraea arcuata, Cotoneaster sp., Caragana sp., Berberis sp., Artemisia sp. etc. Those areas are also important for the medicinal plants as well, such as Androsace sp., Delphinium sp., Dracocephalum heterophyllum, Gentiana sp., Thymus linearis, Lancea tibetica, Potentilla fruticosa, Phlomis rotata, Anaphalis The richness of some very important high triplinervis, Primula sp. etc. The areas where altitude flora and fauna, especially of Tibetan nomads reside were explored by the desert steppe habitat has increased the global KMTNC-ACAP/UMBCP team and importance of Upper Mustang. The animal Dhalung/Chhujung area is confined as one of species like snow leopard, lynx, brown bear, the hot biodiversity hot spot. 


\section{R. Pandey and M. Chetri / Our Nature (2005)3:42-49}

\section{Socio-economic conditions}

The main traditional occupation of nomads is rearing and herding yaks and goats/sheep, they are also involved in some other income generation activities such as trade of livestock, sale of milk and milk products, wool, pashmina etc. Most of the nomads can understand Loba and Tibetan language and only few of them can read and write Tibetan language. But most of them, even cannot speak national language, Nepali. The educational level among them is meager. Only few boys are studying in Lo-Manthang and India. Quite interestingly, one boy is studying in Kathmandu with a financial support from a German and he is the only educated nomad who has completed schooling (Grade X). Nomads do not show their interest in getting Nepalese citizenship because only few have that certificate. They are of the opinion that they never faced any discomfort and snag so that most of them are satisfied with their nomadic life. They can manage all of their needs without any problem. According to them, they have been practicing this kind of life from 5-6 generations ago but nobody knows about the exact time period.

\section{Annual shifting pattern}

The movements of all nomads, throughout the year, are limited within a short territory, particularly during the summer and winter months. They normally shift from highland to lowland during the winter months in order to protect from the severe cold and snowfall. The seasonal shifting pattern varies mostly in Dhalung/Chhujung area, while in other areas that is not as diverse as the family number in Dhalung/Chhujung area. The movement is summarized in table 1 , as given below.

Pasture management and livestock keeping and herding system

Seasonal grazing is a customary practice for all dhokpa families. The pasturelands are categorized into summer and winter pastures. The grazing in winter pasture is restricted during summer months. But in case of Dhalung/Chhujung area, winter grazing can be started only after the consent of three camps whereas no rule has been made to graze in summer pastures. They normally use guard dogs while shepherding and spend all the day in the pastures. Normally, yaks are kept free in the high pasturelands whereas goats/sheep are driven out to graze during the day in the pastures and taken back to goth during the night. In practice, VDCs do not have control over any rules and regulation for nomad families and they decide themselves about their grazing and movements.

The herders from Tibet can easily come to Nepal and graze their livestock even after the enactment of agreement between Nepalese and Chinese governments in 1983. But this agreement does not seem practical for Tibetan herders. Moreover, the Nepalese are not allowed to graze in the Tibetan pasturelands due to the tight security in Tibet. Grazing pressure is increasing day-by-day due to this one-way movement from the Tibet. Nomads are facing problems because of the encroachment. The taxation system for grazing is flexible and depends on the mercy of the people of the concerning village. Even in some cases particularly in Panga area, the people of Chhonup VDC sometimes impose taxes for the outsider nomads of Panga area. Normally grazing is confined within the concerning pastures but in winter, sometimes nomads go to the nearby possible pastures, as for instance nomads of Panga area usually graze their livestock within the same area but during winter they go to Lo-Ghyakar area, Tsarang VDC. Likewise, the dhokpa of Lauchhe/Dhaknak area also go to Ghami Lekh area during winter season for grazing 


\section{R. Pandey and M. Chetri / Our Nature (2005)3:42-49}

for few days.

Nomads generally prefer yaks, goats/sheep and horses for rearing. The composition of livestock owned by nomads is given in table 2. They also graze others people livestock from the village, in return they get money and kinds by bartering with the livestock owners.

Yak number was more in 20 years back, as there was more availability of grasses in the highland pastures. But the number of yaks is decreasing in the recent years. More care is needed to rear the yak than any other livestock. The young ones are often preyed upon by the snow leopard. The number of goats/sheep has somewhat been steady in the past 20 years; except for fluctuations in their numbers in eight years back due to the increase in the cases of predation. Horses are generally raised as the symbolic representation of their status and are also used for transportation and carrying goods.

According to nomads, the grass availability in the pastures is in decreasing trend, for instance, a nomad family in Dhalung/Chhujung area had 15-20 goths in the past but at present it declined up to only 3 goths, which reflects shortage of grasses ultimately resulting the decrease in livestock rearing. All the nomads have a same voice regarding the decrease in grass availability, i.e. less rainfall/snowfall in comparison to the past. Only few families have open goths. Most of them do not have goths and livestock are generally kept openly near their camps and that are confined in only few places. As a result, there is a high risk of predation all the time. According to nomads of Dhalung /Chhujung, the number of blue sheep, snow leopard has increased whereas that of Tibetan gazelle has decreased. Juniperus trees have been uprooted and cut down for timber and fuel wood as a result there is a decrease in the rainfall in the area. Their belief of deterioration of pastures is the annoyance of God. The quantity and quality of grasses have positive effects on the health condition of livestock as well. Both quantity and quality of grasses are not so good as compared to that in the past, so the health status of livestock is average. They are keen to herd their livestock throughout the year even under the adverse circumstances. While shepherding, they have to be vigilant all the time. For that, they watch their animals from a vantage point and often whistle, ring bell, make noise and carry sling while tending their livestock. Fathers and sons often share their works on rotational basis while shepherding. Some go to watch the yaks and some for goats/sheep. During the cloudy days, nomads move along with the herds because the visibility is very poor at that time and there is a high chance of predation and accident. The guard dogs play a very important role during such circumstances.

\section{Livestock mortality faced by nomads}

Depredation can be observed mostly during winter months particularly during December to March where proper guarding is lacking because of severe cold and livestock also become very weak due to lack of forage. Predation generally occurs more when the less availability of grasses tends livestock to the rocky and cliff areas, in the habitats of predators. In Dhalung/Chhujung area, there are two sites Rijiphuwa and Pika, where snow leopard and wolf are the problem creators. Number of losses of livestock in Dhalung/Chhujung area ranges from 5-11 every year. In the upper part of Kara pasture of Panga area, snow leopard is the major problem carnivore, mostly during February and March. But the wolf mostly attacks during summer months. In Lauchhe/Dhaknak 


\section{R. Pandey and M. Chetri / Our Nature (2005)3:42-49}

area, the wolf problem can be seen in proper guarding and use of sling shot and Lauchhe pasture in summer whereas that of make louder voice. Most of them are of the snow leopard can be seen in Dhaknak pasture opinion that depredation of livestock is in during winter months. There are fewer decreasing trend. They generally face problems in Ghami Lekh pasture, where the problems from diseases like foot and mouth cases are sporadic.

Among nine nomads' families, the families of Dhalung/Chhujung area are facing higher number of livestock losses. Within the last 18 months, they have lost 113 goats /sheep and 6 yaks. Next to them are the families of Panga, which lost 8 yaks followed by a family of Lauchhe / Dhaknak- 7 yaks. Five yaks were reported lost by a family of Ghami Lekh as shown in table 3. disease, respiratory infection, diarrhoea, dysentery and scabies. Due to the lack of veterinary services they often complain about this issue. In case of predation, the wolf problem is lessening as the wolf can move freely across the open Nepal-China border and are also being killed by the Tibetans. But the snow leopard problem is unchanged.

Among the total lost, the lost by lack of forage is high $(35.25 \%)$ followed by predation $(34.53 \%)$ and disease $(30.22 \%)$ (Table 4). So it seems that all the above-mentioned causes of mortality are more or less similar. No disease or natural disaster has occurred in the past in the pasturelands used by nomads but the cases of diseases are now increasing due to lack of veterinary care.

\section{Issues and challenges}

It is a challenging task to conserve overall biodiversity of Upper Mustang. There are several components that are responsible to affect the biodiversity. As nomads are also an important entity of this area and their activities are directly related to the biodiversity, it is quite necessary to give focus on their interaction with the nature. Large flocks of goats/sheep often come from Tibet to

But in case of predation, out of 48 total killed yaks and goats/sheep (see table 5), the predation is high due to snow leopard $(56.25 \%)$ followed by gray wolf $(33.33 \%)$ and golden eagle $(10.42 \%)$. Golden eagle killed only the young of goats/sheep. Sometimes eagle also succeed in killing the old and weak ones.

In the present study, the cases of mortality due to other reasons like severe cold/snow and other predators like lynx, jackal and feral dogs were not reported. Nomads of Dhalung/ Chhujung area use their own traditional measures to protect their livestock against predators such as, guarding by man and watch dog, erection of scarecrow, use of slingshot, firing and smoking and use of colorful clothes. Rest of the nomads are not aware of control measures but they believe on

Dhalung/Chhujung area. Nearly 25-30 goths come from Tibet every year and each goth comprises approximately $350-400$ goats/ sheep and yak. Such type of activity is creating grazing pressure on the limited pastureland. Nomads claim this as the main reason for the deterioration of pastures. During the summer months, one can see the nomads coming from Tibet and the grazing areas seem a miniature settlement in Dhalung /Chhujung area. The daily activities of those outsider nomads have creating adverse impacts on the biodiversity of that area. They cut the Caragana sp. and Juniperus tree as firewood and also invasive for the free movement of wildlife in the area. During the summer, the movement of Tibetan gazelle and Tibetan wild ass is badly affected. Till April, the activities of those herbivores can 
M. R. Pandey and M. Chetri / Our Nature (2005)3:42-49

Table 1. The shifting pattern of nomads in Upper Mustang

\begin{tabular}{|c|c|c|c|c|}
\hline \multirow{2}{*}{ SN } & \multirow{2}{*}{ Dhokpa of } & \multicolumn{2}{|c|}{ Place } & \multirow{2}{*}{ Remarks } \\
\hline & & Summer & Winter & \\
\hline 1 & $\begin{array}{l}\text { Panga area, Lo- } \\
\text { Manthang }\end{array}$ & $\begin{array}{l}\text { Dhiple and Dhema- March to } \\
\text { September } \\
\text { Sabade- October to November }\end{array}$ & $\begin{array}{l}\text { Sumdha and Ngilu Karchung- } \\
\text { December to February }\end{array}$ & 3 families \\
\hline 2 & $\begin{array}{l}\text { Dhalung/Chhujung } \\
\text { area, Lo-Manthang }\end{array}$ & $\begin{array}{l}\text { Yarja- Last } 15 \text { days of April to } 1^{\text {st }} \\
15 \text { days of October } \\
\text { Dhalung- May to July ( } 1 \text { family) } \\
\text { Jhyangwatar- September to } \\
\text { October ( } 1 \text { family) }\end{array}$ & $\begin{array}{l}\text { Mapcha- October (Last } 15 \text { days) } \\
\text { and May } \\
\text { Marku Kyunker- November to } \\
\text { February } \\
\text { Riji Phuwa- March and } 1^{\text {st }} 15 \\
\text { days of April }\end{array}$ & 4 families \\
\hline 3 & $\begin{array}{l}\text { Lauchhe/Dhaknak } \\
\text { area, Chhonup }\end{array}$ & $\begin{array}{l}\text { Lauchhe/Dhaknak- Last } 15 \text { days } \\
\text { of March to } 1^{\text {st }} 15 \text { days of October }\end{array}$ & $\begin{array}{l}\text { Chhujung- December to } \\
\text { February) }\end{array}$ & 1 family \\
\hline 4 & $\begin{array}{l}\text { Ghami Lekh area, } \\
\text { Ghami }\end{array}$ & $\begin{array}{l}\text { Mikchyung and Kyu- April to } \\
\text { October }\end{array}$ & $\begin{array}{l}\text { Lha Kyap, Ghami Lekh area- } \\
\text { Last } 15 \text { days of October to } 1^{\text {st }} 15 \\
\text { days of March } \\
\text { Lha Kyap- November to March }\end{array}$ & 1 family \\
\hline
\end{tabular}

\begin{tabular}{|c|c|c|c|c|c|c|}
\hline \multirow{2}{*}{$\mathrm{SN}$} & \multirow{2}{*}{$\begin{array}{l}\text { Type of } \\
\text { livestock }\end{array}$} & \multicolumn{4}{|c|}{ Total Number of livestock in } & \multirow{2}{*}{ Total } \\
\hline & & Panga area & Dhalung/Chhujung,, & Lauchhe/Dhaknak, & Ghami Lekh, , & \\
\hline 1 & Yak & 134 & 126 & 200 & 60 & 520 \\
\hline 2 & Goat/Sheep & 150 & 700 & 90 & 70 & 1010 \\
\hline \multirow[t]{2}{*}{3} & Horse & 5 & 9 & 2 & 2 & 18 \\
\hline & Total & 289 & 835 & 292 & 132 & 1548 \\
\hline
\end{tabular}

Table 3: Number of nomads' livestock reported lost due to different reasons

\begin{tabular}{|c|c|c|c|c|c|c|c|c|c|c|c|}
\hline \multirow{3}{*}{$\begin{array}{l}\text { Type of } \\
\text { livestock }\end{array}$} & \multicolumn{5}{|c|}{ Dhalung/Chhujung area } & \multicolumn{2}{|c|}{ Panga , } & Lauchh & knak , & \multirow{2}{*}{$\frac{\text { Ghami Lekh , }}{\text { P }}$} & \multirow{3}{*}{ Total } \\
\hline & \multirow{2}{*}{ D } & \multirow{2}{*}{$\mathbf{L F}$} & \multicolumn{3}{|c|}{$\mathbf{P}$} & \multirow{2}{*}{ D } & \multirow{2}{*}{$\frac{P}{S L}$} & \multicolumn{2}{|c|}{$\overline{\mathbf{P}}$} & & \\
\hline & & & SL & WF & GE & & & SL & WF & SL & \\
\hline Yak & 0 & 4 & 0 & 2 & 0 & 1 & 7 & 4 & 3 & 5 & 26 \\
\hline Goat/Sheep & 41 & 45 & 11 & 11 & 5 & 0 & 0 & 0 & 0 & 0 & 113 \\
\hline Total & 41 & 49 & 11 & 13 & 5 & 1 & 7 & 4 & 3 & 5 & 139 \\
\hline
\end{tabular}

Note: $\mathrm{D}=$ Disease; $\mathrm{LF}=$ Lack of forage; $\mathrm{P}=$ Predators; $\mathrm{SL}=$ Snow leopard; $\mathrm{WF}=$ Wolf; and $\mathrm{GE}=$ Golden eagle

Table 4. Total Number of perceived livestock losses (case wise).

\begin{tabular}{lll}
\hline SN & Type of mortality & Total \\
\hline 1 & Lack of forage & $49(35.25 \%)$ \\
2 & Predation & $48(34.53 \%)$ \\
3 & Disease & $42(30.22 \%)$ \\
& Total & $\mathbf{1 3 9}$ \\
\hline
\end{tabular}

Table 5. Total number of perceived predation

\begin{tabular}{cll}
\hline SN & Problem predator & \multicolumn{1}{c}{ Number lost } \\
\hline 1 & Snow leopard & $27(56.25 \%)$ \\
2 & Gray wolf & $16(33.3 \%)$ \\
3 & Golden eagle & $5(10.42 \%)$ \\
& Total & $\mathbf{4 8}$ \\
\hline
\end{tabular}


be seen satisfactorily but after May to till October it is difficult to watch their movement. As Nepalese nomads are very keen to follow their own traditional rules and regulation, it is quite interesting to note that the biodiversity of nomads' residing areas are not adversely affected. The main impacts on biodiversity are uprooting of Caragana sp., cutting of few juniper shrubs and trees and collection of huge amount of dung. More than half of the animal dung is burnt as fuel and few are sold to the villagers that minimize the soil nutrition of the pasturelands. The health condition of rangeland is also affected due to over grazing. All the activities of nomads of Tibet are the key issue to be addressed. If there encroachment continues, more negative impacts will definitely be seen in the future and if the ecosystem of this area cannot be considered on time, problems will occur in the future as well.

\section{Conclusion}

The present study has revealed some facts on the existing nomadic life and their interaction with livestock. As livestock rearing is the main occupation of nomads, grazing in pasturelands and the daily activities directly affect the biodiversity of the area. In all nomads' areas, there is a regular practice of collection of Caragana sp. and other plant species as firewood and collecting desired shrubs in desired quantity has been difficult for them. The mode of using these plants is also one of the major demands of shrubs and Juniperus trees. The predation, lack of forage and diseases are the problems faced by the nomads and it is right time to take initiative to mitigate those problems by different measures such as conservation awareness, systematized herding practices, promoting infrastructure development like predator proof corral construction, water holes, promoting veterinary care and so on. Till now, nomadism is not considered as a problem for the biodiversity conservation but the encroachment by the Tibetan herders and nomads are the major issues of concern. Their interferences directly creating the grazing pressure on Nepalese pasturelands and even the free movement of wildlife.

\section{Acknowledgements}

We are grateful to KMTNC-ACAP/UMBCP for getting the opportunity to work in Upper Mustang. Thanks are due to Rangers Mr. Amar Gurung, Mr. Basu Dev Neupane, Mr. Heera Bahadur Chhetri and Mr. Chhimi Rinjin Gurung, Secretary of Conservation Area Management Committee, Lo-Manthang for collecting information.

\section{References}

Shah, K.B. 2001. Preliminary survey of biodiversity in Upper Mustang. UMBCP Research Report Series 4.

UMBCP, Reports. 2001-2005. 